Navigation Physics 2(2) (2020)
Navigation Physics
Journal of Physics Education

\title{
Penerapan Metode Pembelajaran Problem Based Learning Guna Meningkatkan Hasil Belajar IPA Di Masa Pandemi Covid 19
}

\author{
Sri Mulyani ${ }^{1 *}$ \\ ${ }^{1}$ SD Negeri Karangwuni 03 \\ *E-mail: smulyani.karangwuni3@gmail.com
}

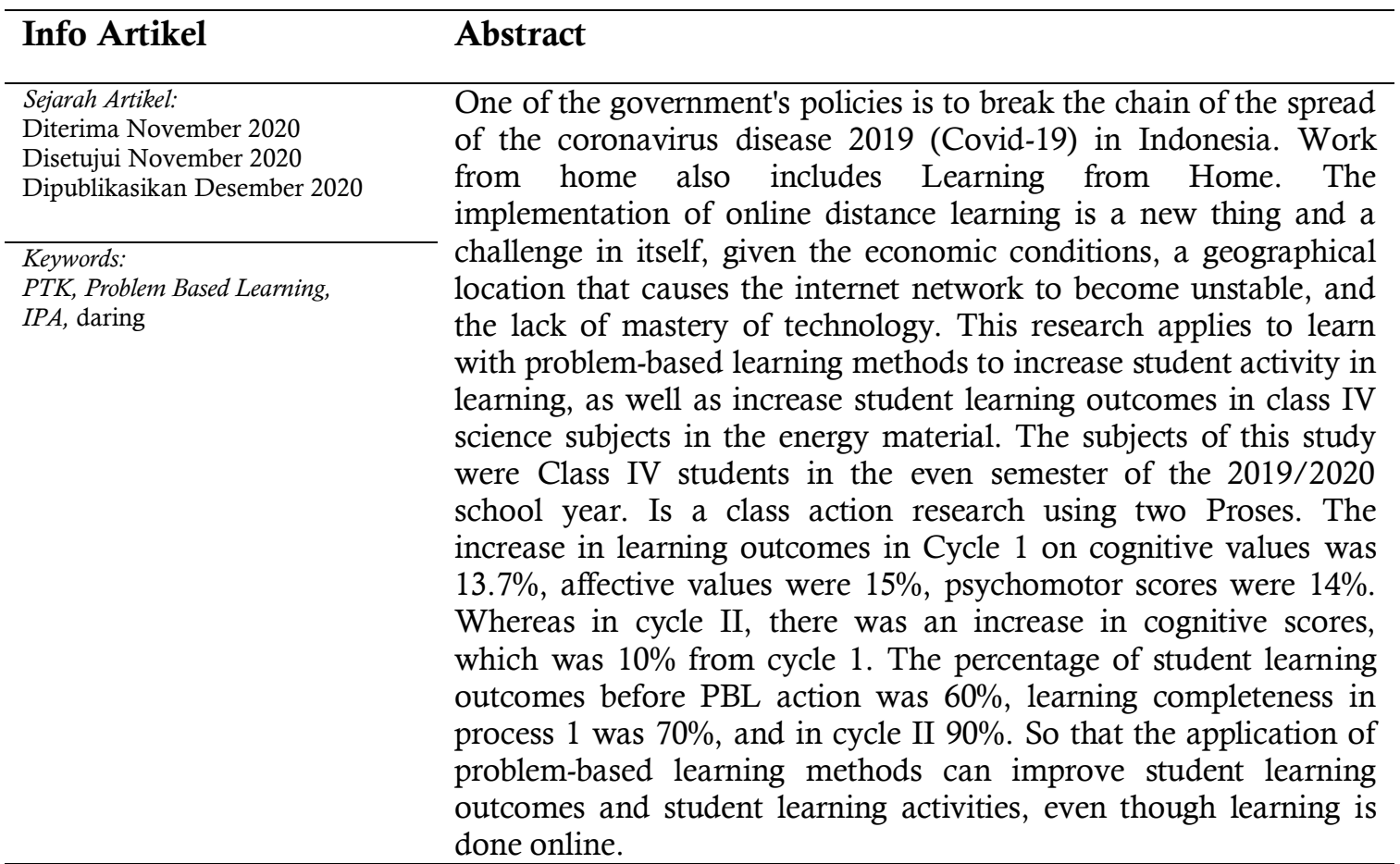

How to Cite: Mulyani, S. (2020). Penerapan Metode Pembelajaran Problem Based Learning Guna Meningkatkan Hasil Belajar IPA Di Masa Pandemi Covid 19. Navigation Physics, 2 (2): 84-89.

\section{PENDAHULUAN}

Pandemi corona virus disease 2019 (Covid-19) yang melanda Dunia, Khususnya Indonesia membuat pemerintah menghimbau warga nya untuk stay at home, membatasi aktivitas di luar rumah, juga pembatasan kontak langsung dengan sesama manuasia (Physical distancing). Salah satu kebijakan merintah untuk memutus mata rantai penyebaran virus Corona dii Indonesia Bekerja dari rumah (Work From Home), juga termasuk Belajar dari rumah (Study From Home). Menurut Surat Edaran Mendikbud NO. 4/2020 tentang pelaksanaan pendidikan dalam masa darurat Covid-19 dapat dilakukan melalui pembelajaran jarak jauh (PJJ) (Handayani, 2020). Keberhasilan pendidikan dalam situasi pandemic Covid-19 berasal dari kolaborasi dan interaksi tiga elemen yaitu Guru, Siswa dan Orang Tua.

Pelaksanaan pembelajaran jarak jauh melalui online merupakan hal baru dan menjadi tantangan tersendiri bagi murid, juga guru di SD Negeri Karangwuni 03, kecamatan Weru, Kabupaten Sukoharjo, Jawa Tengah. Beberapa faktor yang menyebabkan terhambatnya pelaksanaan pembelajaran online adalah; kondisi ekonomi, letak geografis yang menyebabkan jaringan internet tidak stabil, serta penguasaan teknologi yang masih kurang. Pembelajaran online tidak hanya melibatkan interaksi siswa dan guru, melainkan perlu pendampingan dan kerjasama dari orang tua siswa itu sendiri. Oleh karena itu, sebagai guru kelas IV di SD Negeri Karangwuni harus memiliki inovasi dan kreatif dalam menerapkan model 
pembelajaran. Pada awal SFH pembelajaran berbasis online diterapkan dengan memberikan materi dan penugasan melalui link yang di share melalui WhatApp, namun hasil belajar siswa masih banyak yang berada dibawah KKM, dan beberapa siswa juga kurang aktif dalam pembelajaran tersebut. Sehingga perlu diterapkan metode pembelajaran lainnya, yang dirasa efektif dan membantu siswa dalam memahami mata pelajaran terutama IPA pada materi Energi.

Dalam penelitian (De Jong et al., 2013), metode Teach Centered Learning ( TCL) membuat siswa pasif karena proses pembelajaran hanya berpusat kepada guru. Oleh karena itu, perlu melakukan perubahan paradigma tentang proses pembelajaran yang harus melibatkan siswa untuk meningkatkan pemahaman tentang konsep dan materi yang disajikan. Metode Students Centered Learning (SCL) dapat mendorong dan memotivasi siswa untuk berpartisipasi aktif (E. K. Wati \& Widiansyah, 2020), memiliki kekuatan kritis, dapat menganalisis, dan dapat menyelesaikan masalah (Prima et al., 2018). Dalam proses pembelajaran sebagai guru, kita dapat menggunakan beberapa metode pembelajaran untuk menciptakan suasana belajar yang menyenangkan. Dengan demikian, kita harus menguasai berbagai teknik, model, atau teknologi pembelajaran (Smetana et al., 2012) ( Wati, 2020).

Guna mengubah paradigma pembelajaran yang berpusat oleh guru, dalam penelitian ini akan melakukan inovasi pembelajaran dengan metode pembelajaran yang berpusat pada siswa (Student Centered Learning). Salah satu metode pembelajaran yang berpusat pada siswa (SCL) yakni metode Problem Based Learning, yang merupakan model pembelajaran dengan melibatkan siswa dalam memecahkan masalah nyata/langsung. Penerapan metode Problem Based Learning pada pelajaran IPA dapat meningkatkan kemampuan berpikir kritis mengidentifikasi, menganalisis, serta memecahkan masalah (Fakhriyah, 2014) (Yandhari et al., 2019). Penerapan PBL juga dapat meningkatkan prestasi belajar dan aktifitas siswa (Widayanti \& Dwi Nur'aini, 2020) (Diarini et al., 2020). Metode PBL merupakan model pembelajaran yang menyenangkan dan menarik bagi siswa saat melakukan pembelajaran secara online (Giyarsi, 2020) (Istyadji, 2018) (Setiawan et al., 2019) (Rosidah, 2020). Sehingga dalam penelitian ini untuk akan menerapkan pembelajaran berbasis masalah guna meningkatkan hasil belajar siswa pada Mata pelajaran IPA materi Energi pada kelas IV SD Negeri Karangwuni 03. Pembelajaran dengan metode PBL ini akan mempelajari pengetahuan yang berkaitan dengan masalah tersebut, sekaligus siswa diharapkan akan memilki keterampilan dalam memecahkan masalah yang sedang dihadapi dan mampu meningkatkan hasil belajar siswa.

\section{METODE PENELITIAN}

Penelitian ini merupakan Penelitian Tindakan Kelas dengan Metode pembelajaran yang diterapkan adalah metode Problem Based Learning (Diarini et al., 2020) (Yandhari et al., 2019), pada Mata pelajaran Ilmu Pendidikan Alam materi pokok Energi. Subjek penelitian ini Siswa Kelas IV pada Semester Genap Tahun ajAran 2019/2020. Penelitian Tindakan kelas akan dilakukan dengan menggunakan 2 siklus. Masing-masing siklus memiliki tahapan perencanaan, pelaksanaan, tindakan, observasi dan refleksi.

Siklus satu meliputi empat tahapan (1). Tahap Perencanaan; penyusunan Rencana Persiapan Pembelajaran (RPP), menyiapkan alat dan bahan/media pembelajaran, menyiapkan soal/permasalahan yang sesuai dengan karakteristik siswa, materi yang diajarkan, dan membuat instrumenpenelitian. (2). Tahap Tindakan; dilaksanakan pembelajaran sesuai dengan RPP yang telah disusun. (3). Tahap Observasi dan Evaluasi. Kegiatan observasi dan evaluasi ini dilaksanakan secara daring melalui video conference, juga melalui video yang dikirmkan oleh maisng-maisng siswa. Segala kejadian dalam pembelajaran diamati dan didokumentasikan sebagai bahan kegiatan refleksi. Pada akhir siklus diadakan kegiatan evaluasi. (4). Tahap Refleksi; pada tahapan ini menganalisis proses sebelumnya, baik kelemahan dan kelebihannya sehingga diperoleh kesimpulan mengenai keberhasilan dan kekurangan proses pembelajaran dengan metode PBL pada siklus 1 . Hasil kesimpulan akan digunakan untuk memperbaiki tindakan pada siklus selanjutnya.

Instrumen yang digunakan dalam penelitian ini adalah instrumen untuk melakukan pembelajaran dan instrumen pengumpul data penelitiaan: (1)Instrumen Pembelajaran; berupa silabus, RPP, LKS, serta alat peraga pembelajaran; (2)Tes hasil belajar dalam instrumen ini berupa soal pilihan dan essay. Jumlah soal Soal prestasi ini divalidasi logis terlebih dahulu sebelum diujikan untuk menilai hasil prestasi belajar siswa. Untuk memenuhi validasi logis, penyusunan soal didahului dengan pembuatan kisi-kisi soal yang sesuai dengan Standar Kompetensi dan Kompetensi Dasar; (3)Lembar Pengamatan Siswa Lembar pengamatan siswa ialah lembar yang digunakan untuk menilai siswa ketika kegiatan praktikum secara individu dan presentasi secara berekelompok. Penilaian ini digunakan untuk mengukur hasil belajar siswa pada aspek afektif dan psikomotor 
Teknik pengumpulan data pada penelitian ini ; terdapat tiga macam data yang akan diambil yaitu data hasil belajar siswa aspek kognitif, afektif, dan psikomotor. Pengambilan data dilakukan pada masingmasing siklus. Dalam proses pembelajaran dengan metode Problem Based Learning siswa dinilai dengan lembar penilaian psikomotor dan penilaian pada aspek afektif. Selanjutnya siswa mngerjakan soal evaluasi sebagai penilaian pada aspek kognitif. Penilaian pada ketiga aspek ini diberikan dengan tujuan untuk mengetahui peningkatan hasil belajar siswa. Dengan membandingkan rata-rata skor hasil tes antar siklus dapat diketahui pengaruh metode PBL pada peningkatan hasil belajar IPA.

\section{HASIL DAN PEMBAHASAN}

Penelitian Tindakan Kelas ini terdiri dari 2 siklus, yaitu siklus I dan siklus II yang masing- masing siklus terdiri dari 4 kegiatan antara lain: perencanaan, pelaksanaan tindakan, observasi kegiatan tindakan kelas, dan refleksi.

Secara rinci kegiatan PTK pada Siklus 1 adalah sebagai berikut; (1) Tahap perencanaan tindakan yaitu Merencanakan tanggal pelaksanaan pembelajaran, mencermati dan mengembangkan silabus, standar kompetensi dan kompetensi dasar pada materi Energi Panas, membuat Rencana Pelaksanaan Pembelajaran dengan penerapan pembelajaran dengan metode Problem Based Learning yang meliputi kegiatan awal kegiatan inti dan kegiatan penutup, membuat materi, menyiapkan sumber belajarm menyiapkan materi pembelajaran sesuai dengan metode pembelajaran, membagi tugas praktikum masingmasing siswa, menyusun lembar kerja siswa, membuat format observasi selama proses pembelajaran dan membuat kisi-kisi soal ulangan harian, membuat butir soal ulangan harian dan membuat skor penilaian, membuat format analisis pencapaian ketuntasan belajaran; (2) Tahap pelaksanaan tindakan pada kegiatan apersepsi, guru melakukan tanya jawab dengan siswa. misalnya: mengapa setiap hari perlu makan? mengapa pakaian bisa kering saat dijemur? mengapa ketika menggosok-gosokan tangan terasa panas? Pada orientasi kegiatan guru menyampaikan tujuan pembelajara yang akan dicapai. Serta memberi motivasi bahwa Pelajaran ini perlu dipahami, karena materi energi panas bukan sekedar pelajaran di sekolah, peristiwa tersebut juga dijumpai dalam kehidupan sehari-hari oleh karena itu penting memahami hal ini, guna mengetahui manfaat energi panas dalam kehidupan sehari-hari. Pada kegiatan inti Siswa secara mandiri/individu melakukan percobaan/praktikum mengenai sumber panas. Upaya kegiatan ini guna membuata siswa lebih aktif dalam pembelajaran, siswa diberi tugas untuk membuat laporan mengenai sumber-sumber energi dan kegunaan, Siswa memresentasikan hasil praktikum \& laporan ketika pembelajaran secara online, pada minggu selanjutnya. Pada kegiatan elaborasi Siswa melakukan kegiatan praktikum dirumah masing-masing, semua kegiatan tersebut direkam menggunakan Hp, sebagai hasil laporan kegiatan tersebut, Siswa membuat laporan mengenai sumber-sumber energy dan kegunaannya Siswa menanggapi laporan atau pendapat teman dan mengajukan argumentasi dengan santun. Kegiatan guru dalam konfirmasi yaitu memberi penghargaan kepada peserta didik yang aktif dan yang benar dalam melaksanakan praktikum, berdasarkan video rekaman yang dikirimkan oleh masing-masing siswa, memberi motivasi kepada peserta didik yang kurang aktif serta kurang tepat dalam melakukan praktikum. ( jika yang melakukan praktikum orangtua siswa, maka diarahkan agar siswa sendiri yang melakukan kegiatan praktikum tersebut, Guru melakukan Tanya jawab, dan Guru memberikan penegasan dan penguatan materi mengenai energy panas, dan sumber-sumber energi panas serta manfaatnya. Terakhir adalah Kegiatan Penutup Bersama siswa membuat rangkuman materi, mengadakan evaluasi, melakukan refleksi dan dilanjutkan dengan tindak lanjut.mengadakan penilaian dan analisis nilai, memberikan PR dan menutup pelajaran melalui daring yakni conference (Daniati, Bambang Ismanto, 2020); (2) Tahap Observasi Pembelajaran merupakanPengamatan dilaksanakan secara intensif dan berkelanjutan. Data yang dikumpulkan meliputi data hasil belajar kognitif, afektif, dan psikomotor pada Tabel 1; (3) Tahap Refleksi pada tahapan ini melakukan evaluasi hasil pengamatan proses pembelajaran untuk mengetahui hasil belajar afektif, psikomotor, dan kognitif, Menilai video rekaman praktikum siswa, tugas harian, dan presentasi hasil praktikum dan tugas kelompok, menganalisis hasil ulangan harian dan LKS. Berdasarkan Tabel 1. Hasil belajar siswa masih kurang maksimal terutama pada aspek kognitif dan psikomotor oleh karena itu diperlukan siklus II untuk penerapan model PBL agar pencapaian hasil belajar siswa lebih meningkat lagi.

Tabel 1. Hasil belajar siswa pada siklus I

\begin{tabular}{clc}
\hline No & Aspek Penilian & Rata-rata Nilai \\
\hline 1 & Kognitif & 84.3 \\
2 & Afektif & 85
\end{tabular}


Pelaksanaan tindakan kelas siklus II, hmapir sama dengan siklus I juga terdapat empat tahap: (1) perencanaan; (2) pelaksanaan tindakan; (3) observasi kegiatan tindakan kelas; (4) refleksi. Akan tetapi terdapat perbaikan yang perlu dilakukan berdasarkan tahapan refleksi pada siklus I. pada tahap pelaksanaan tindakan pada siklus ini siswa bekerja secara kelompok (Susanto, 2020), pembagian kelompok kecil berdasarkan materi perpindahan panas; Konduksi, konveksi dan radiasi. Semua tahapan hampir sama seperti pada siklus I, yang berbeda hanyalah tahap I siswa bekerja secara mandiri/individu sedangkan pada siklus II siswa bekerja secara kelompok. Pada siklus ini, siswa dituntut untuk mampu bekerja sama dalam tim atau kelompok belajar. Hasil pembelajaran pada siklus II ditampilkan pada Tabel 2.

Tabel 2. Hasil belajar siswa pada siklus II

\begin{tabular}{rlc}
\hline No & Aspek Penilian & Rata-rata Nilai \\
\hline 1 & Kognitif & 95 \\
2 & Afektif & 85 \\
3 & Psikomotor & 85 \\
\hline
\end{tabular}

Berdasarkan Tabel 2 nilai hasil belajar siswa pada siklus II pada aspek kognitif yang diperoleh dari penilaian hasil evaluasi yang telah dilakukan yaitu memiliki rata-rata 95, Hasil belaja pada aspek afektif diperoleh dari penilaian hasil pengamatan terhadap sikap siswa yang dilakukan selama kegiatan KBM berlangsung yang menitik beratkan yang menitik beratkan pada segi pemahaman, kerja sama dan menghormati pendapat orang lain yaitu dengan rata-rata 85 , dan pada aspek psikomotor diperoleh dari penilaian hasil pengamatan terhadap partisipasi atau sikap aktif siswa yang dilakukan selama proses pembelajaran berlangsung adalah dengan rata-rata 85 .

Untuk mengetahui hasil peningkatan belajar siswa dengan menggunakan menerapkan metode pembelajaran problem based learning secara detail akan ditampilkan pada Tabel 3 berikut ini

Tabel 3. Rekapitulasi peningkatan hasil belajar siswa

\begin{tabular}{lllll}
\hline No & Tindakan & \multicolumn{3}{c}{ Penilaian } \\
& & Kognitif & Afektif & Psikomotor \\
\hline 1 & Sebelum $P B L$ & 70,6 & 70 & 70 \\
2 & Siklus 1 & 84.3 & 85 & 84 \\
3 & Siklus II & 95 & 85 & 85 \\
\hline
\end{tabular}

Pada Tabel 1 menunjukkan nilai rata-rata hasil belajar siswa pada mata pelajaran IPA kelas IV sebelum menerapkan metode PBL adalah 70.6 untuk nilai kognitif, nilai pada aspek afektif dan kognitif adalah 70 . Sedangkan setelah dilaksanakan penelitian tindakan kelas dengan metode PBL rata-rata hasil belajar siswa pada aspke kognitif adalag 84.3, rata-rata pada aspek afektif 85 dan aspek psikomotor adalah 84. jika dibandingkan antara sebelum dan sesudah dilakukan tindakan kelas pada siklus 1 maka terjadi peningkatan hasil belajar sebesar $13.7 \%$ pada nilai kognitif yang diperoleh dari penilaian tugas dan ulangan harian, untuk peningkatan hasil belajar afektif sebesar $15 \%$ diperoleh dari penilaian hasil pengamatan terhadap sikap siswa yang dilakukan selama KBM berlangsung yang menitik beratkan pada segi ketelitian, tanggung jawab dan demokratis, dan peningkatan $14 \%$ pada aspek psikomotor yang diperoleh dari penilaian hasil pengamatan terhadap partisipasi atau sikap aktif siswa yang dilakukan selama KBM berlangsung. Untuk hasil belajar pada siklus II jika dibandingkan dengan sebelum tindakan juga jauh lebih menunjukkan adanya peningkatan yang maksimal, sebesar $24.4 \%$ peningkatan terjadi pada aspek kognitif, peningkatan nilai di aspek afektif sebesar 15\%, dan untuk hasil belajar pada aspek psikomotor terjadi peningkatan sebesar $15 \%$. Peningkatan hasil belajar pada siklus I dan II terlihat berbeda untuk nilai pada aspek kognitif, dan psikomotor, sedangkan untuk nilai afektif siklus I dan siklus II menunjukkan hasil yang sama. Peningkatan nilai hasil belajar pad siklus II disebabkan karena pembelajaran pada siklus II siswa bekerjas secara kelompok, sehingga dalam kegiatan tersebut mereka bisa berdiskusi dan bertukar pendapat dalam menyelesaikan masalah, juga masing-masing siswa belajar untuk menghormati dan menghargai pendapat oranglain sehingga siswa mampu bekerja sama dengan baik antar siswa satu dengan yang lainnya. Hal tersebut dapat lebih meningkatkan hasil belajar siswa dari segi kognitif, psikomotor juga afektif. 
Berdasarkan hasil penelitian dan pembahasan maka dapat disimpulkan bahwa penerapan pembelajaran dengan metode Problem Based Learning merupakan metode yang menarik bagi siswa meskipun mereka melakukan pembelajaran secara online. PBL memotivasi siswa untuk berpikir kritis dalam mengidentifikasi, menganalisis, serta memecahkan masalah yang berkaitan dalam kehidupan sehari-hari mereka. sehingga siswa lebih mudah memahami materi pelajaran dengan baik. Hal tersebut terbukti dari peningkatan hasil belajar siswa pada siklus I yaitu pada nilai hasil belajar Kognitif, Afektif, dan Psikomotor. Sedangkan penerapan metode pembelajaran berbasis masalah dikolaborasikan dengan kerja kelompok lebih dapat meningkatkan hasil belajar kognitif, dan psikomotor.

\section{PENUTUP}

Berdasarkan hasil belajar siswa pada Mata Pelajaran IPA Kelas IV di SD Negeri Karangwuni 03 terdapat peningkatan hasil belajar antara sebelum dan sesudah diterapkan metode pembelajaran Problem Bsed Learning yaitu sebesar $24.4 \%$ pada aspek kognitif, peningkatan nilai di aspek afektif sebesar $15 \%$, dan untuk hasil belajar pada aspek psikomotor terjadi peningkatan sebesar $15 \%$. Dengan demikian dapat disimpulkan bahwa penerapan metode PBL dapat meningkatkan hasil belajar IPA di Kelas IV SD Negeri Karang Wuni 03 pada pembelajaran secara online di masa pandemic Covid 19

\section{DAFTAR PUSTAKA}

Daniati, Bambang Ismanto, D. I. L. (2020). Upaya Peningkatan Motivasi dan Hasil Belajar Mahasiswa dengan Penerapan Model Pembelajaran E - Learning Berbasis Google Classroom pada Masa Pandemi Covid-19. Jurnal Hasil Penelitian Dan Kajian Kepustakaan Di Bidang Pendidikan, Pengajaran Dan Pembelajaran, 6(3), 601-608.

De Jong, T., Linn, M. C., \& Zacharia, Z. C. (2013). Physical and virtual laboratories in science and engineering education. Science, 40(6130), 305-308.

Diarini, I. G. A. A. S., Ginting, M. F. B., \& Suryanto, I. W. (2020). Penerapan Model Pembelajaran Project Based Learning Berbasis Lesson Study Melalui Pembelajaran Daring Untuk Mengetahui Kemampuan Berfikir Kritis Dan Hasil Belajar. Ganaya: Jurnal Ilmu Sosial Dan Humaniora, 3(2), 253 265.

Fakhriyah, F. (2014). Penerapan problem based learning dalam upaya mengembangkan kemampuan berpikir kritis mahasiswa. Jurnal Pendidikan IPA Indonesia, 3(1), 95-101.

Giyarsi. (2020). Strategi Alternatif Dalam Pembelajaran Daring Pendidikan Agama Islam Pada Masa Pandemi Covid. Meskipun Banyak Hasil Penelitian Yang Membahas Tentang Permasalahan Pembelajaran Pendidiakan Agama Islam (PAI) Di Masa Pandemi COVID 19 Baik Berupa Skripsi, Tesis Maupun Jurnal, Namun Belum Ada Penelitian Yang Lebih Spesifik Dan Komprehensif Dalam Membaha, 7(1), 224-244.

Handayani, L. (2020). Peningkatan Motivasi Belajar IPA Melalui Model Pembelajaran Project Based Learning pada Masa Pandemi Covid-19 bagi Siswa SMP Negeri 4 Gunungsari. Jurnal Paedagogy, 7(3), 168. http://ojs.ikipmataram.ac.id/index.php/pedagogy/article/view/2726

Istyadji, M. (2018). Implementation Of Problem Based Learning Assistance Of Online Discussion on Problem Solving Ability and Results of Chemical Learning In Supporting. Journal of Chemistry And Education, 1(3), 237-244.

Prima, E. C., Putri, A. R., \& Rustaman, N. (2018). Learning solar system using PhET simulation to improve students' understanding and motivation. Journal of Science Learning, 1(2), 60.

Rosidah, C. T. (2020). Inventa: Jurnal Pendidikan Guru Sekolah Dasar Teknik Literasi Silang Dalam Model Problem Based Learning : Alternatif Pembelajaran di Masa Pandemi Covid19 Pendahuluan Tahun 2020 dunia sedang mengalami Berdasar pada Surat Orang di Indonesia Positif Corona . 04(2).

Setiawan, A. R., Puspaningrum, M., \& Umam, K. (2019). Pembelajaran Fiqh Mu'Āmalāt Berorientasi Literasi Finansial. TARBAWY: Indonesian Journal of Islamic Education, 6(2), 187-192.

Smetana, L. K., \& Bell, R. L. (2012). Computer simulations to support science instruction and learning: A critical review of the literature. International Journal of Science Education, 34(9), 1337-1370.

Susanto, S. (2020). Efektifitas Small Group Discussion Dengan Model Problem Based Learning Dalam Pembelajaran Di Masa Pandemi Covid-19. Jurnal Pendidikan Modern, 6(1), 55-60. 
Wati, E. K., \& Widiansyah, N. (2020). Design of learning media: Modeling \& simulation of building thermal comfort optimization system in building physics course. Jurnal Pendidikan IPA Indonesia, 9(2), 257-266.

Wati, Erna Kusuma. (2020). Penggunaan Software Optimasi Pencahayaan Sebagai Media Pembelajaran Mata Kuliah Fisika Bangunan. SAP (Susunan Artikel Pendidikan), 4(3).

Widayanti, R., \& Dwi Nur'aini, K. (2020). Penerapan Model Pembelajaran Problem Based Learning untuk Meningkatkan Prestasi Belajar Matematika dan Aktivitas Siswa. Mathema: Jurnal Pendidikan Matematika, 2(1), 12.

Yandhari, I. A. V., Alamsyah, T. P., \& Halimatusadiah, D. (2019). Penerapan Strategi Pembelajaran Problem Based Learning Untuk Meningkatkan Kemampuan Pemecahahan Masalah Matematis Siswa Kelas IV. Kreano, Jurnal Matematika Kreatif-Inovatif, 10(2), 146-152. 